\title{
Mediterranean Sea of Educational Culture: Personal Narration of a Peer Learning Activity
}

\author{
Kalathaki Maria ${ }^{1,2, *}$ \\ ${ }^{1}$ School Advisor for Secondary Science Teachers of West Crete, Greece \\ ${ }^{2}$ Regional Directorate of Primary \& Secondary Education of Crete, Greece \\ *Correspondence: School Advisor for Secondary Science Teachers of West Crete, Greece. E-mail: \\ Kalathakimaria.edu@gmail.com
}

Received: April 19, 2018

Accepted: May 29, 2018 Online Published: June 13, 2018

doi:10.5430/wje.v8n3p65

URL: https://doi.org/10.5430/wje.v8n3p65

\begin{abstract}
In this paper is describing an initiative in cultural, outdoor science education that took place in the west Crete-Greece (Chania \& Rethymnon counties) in 2015, and organized in collaboration with teachers and social bodies, to connect Science, Education and Local Communities for a better quality of everyday life. The initiative concentrated in organizing the European Educational Conference "Mediterranean Sea Connects Us: Progress in Education with Local Communities", which hosted as a training program that can be applied elsewhere, with different target groups, promoting the aims of participatory acquisition of knowledge by sharing them in company, with experiential activities in moments of joy, happiness and wisdom. Educators-officials of high level and much experienced in the three levels of Education from Greece, Cyprus, Turkey and Romania, with representatives from local bodies, were invited to deposit experience, aspects, ideas and expectations on future educational collaboration in the area of Balkans, East Mediterranean and widely. As coexisting in the same geographical area, with long and important common past, as collaborators in educational projects from the past, intended to be partners in important and innovative future jointed actions in cultural STEM Education, for the progress of Mediterranean local educational communities.
\end{abstract}

Keywords: teacher training, educational pathways, training pathways, open conference, workshop, peer learning activity, Mediterranean Sea

\section{Introduction}

People's ideas and the way of thinking come from, and can be controlled by, three different but interesting fields: the direct sensory perception of the world, their participation in everyday life with discussions, newspapers, television, internet etc., and the formal education that takes place mainly at schools. A constant problem for science teaching was to preserve these spaces in a kind of harmonious development and to help educators and students understand how these three fields interact (Matthews, 1994). The Earth Charter ends with a conclusion entitled "The Way Forward", where is referred that never before in history, common destiny beckons us to seek a new beginning. This requires a change of mind and heart. It requires a new sense of global interdependence and universal responsibility. We must imaginatively develop and apply the vision of a sustainable way of life locally, nationally, regionally, and globally. The cultural diversity is a precious heritage and different cultures will find their own distinctive ways to realize and share the vision. People must deepen and expand the global dialogue that generated the Earth Charter, because they have much to learn from the ongoing collaborative search for truth and wisdom (Earth Charter, 2000).

Primitive queries in Coordinators' thoughts defined the framework and the text of the Conference's announcement, in order the Conference, where the describing Peer Learning Activity was applied, to be much different from the usual of the Academics. There were more to be discussed than those enclosed to the speeches, many questions, and variety answers. Questions written on the walls of the Museum of National Antiquities of Stockholm helped the organizer to realize the need of a peer learning activity for teachers, a conference that could emerged answers to the questions 'where are we coming from', 'where are we going', 'who do we live with', 'how we meet with other 
worlds', 'what guides our lives', 'how large is our world', etc (Hejll \& Klippstom, 2007). Since the participants are educators, executives and intellectuals in duty of implementing and designing future educational policy in the countries of origin, all the questions could be concentrated in those 'how we can organize and arrange our world', and 'who can tell our story'.

People, from the beginning of the human existing, has striven to explain the world around and to build on the achievements of science and technology in order to improve the quality of life. Aegean insular civilization was built on the need for exploration, and the Aegean Sea became a commercial road of communication and transfer knowledge and ideas among the peoples of the Eastern Mediterranean, in the crossroad of East and West, North and South of Europe and the world widely. By traveling, the islanders came into contact with other societies and cultures and opened up their spiritual horizons, creating a particular social character that combined the conservatism of small societies with a liberal perception of the world, which it constantly challenged, because of the diversity in exploration and discovery (Ntoumas, 2008). In 2014, Greece and Italy who had the Presidency of the Council of the European Union declared 2014 as "Year of the Mediterranean" in order to work together in the framework of the Integrated Maritime Policy to promote activities in the south neighborhood of Europe. Sea is the key element of the Greek identity and of European history. It can be a horizontal priority for the Mediterranean populations and a factor of growth and collaboration in Europe, an area of common research in Education, Science and Culture, a vehicle to overcome the crisis and lead to the progress (www.gr2014.eu).

The participants to the Conference "Mediterranean Sea Connects Us: Progress in Education with Local Communities", living in the same geographical area, in the East Mediterranean Sea, in countries with long and important common past, as collaborators in previous educational projects, intended to be partners in innovative future educational actions through jointed educational and training projects on Science and Technology for the progress of Mediterranean local communities (Kalathaki, 2015). In nowadays, Science Education is negotiated in a cultural more societal framework, overviewing the district cognitive objects of the past, connecting more to the everyday and quality of life. The Association for Science Education (ASE) and the Science Across the World, as active professional learning communities, among many others in Science Education, bring an international dimension to Science Education in schools and colleges. In these frameworks, students gain a global perspective on scientific issues related to their personal lives, their impacts on the environment and the varying cultural impacts of Science on people in different countries. They exploring Science locally and sharing insights globally (ASE website).

In December 2015, the above referred European Educational Conference organized in West Crete, with participants from the East Mediterranean, to discuss on future strategic educational policies and prepare jointed projects on Science, Education with Local Communities. The Conference was an open peer learning activity, a training seminar where lecturers and interlocutors were simultaneously trainers and trainees in the wide learning environment of the local communities of Crete. Continuing professional development is a professional duty for teachers, professors and school heads in the majority of European countries, where a variety of training institutions offer school leadership courses. Teacher profession is for lifelong learners, since teachers need to continue their professional development throughout their careers (EACEA/Eurydice, 2013). Teachers, and their employers recognize the importance of acquiring new knowledge, and are able to innovate and use evidence to inform their work. It is, also, a mobile profession, since mobility is a central component of initial and continuing teacher education programs. As it is said, travel is the only thing you buy that makes you richer. With European funding mobility is supported much in the field of Education and teachers are encouraged to work or study in other European countries for professional development purposes. It is a profession based on collaboration and partnership, as far as teacher education institutions organize their work collaboratively, in teaching and in the research, many times with schools, in local learning environments, with work based training providers and other stakeholders (SEC, 2007).

\section{Methodology}

The paper is a personal narration about the experience of organizing an educational/training open Conference, an experiential peer teaching and learning activity with inquiry and discovery in the fields of Science, Philosophy, History, Pedagogy, in the Education of the Mediterranean civilization, the beauty of Cretan nature, and with local communities. The narration based on exploring the digital and printed archival material that concentrated during the educational open Conference that took place in West Crete in December of 2015. The exploration of the archival material was carried out with a non-constructive way. In the delivered texts, photographs, videos, were sought innovative elements, analogues and parallelisms, in a historical reflection, in order to answer some questions and to knit the entire narrative around the memories of the coordinator and writer of the present paper (Iosifidis, 2003). A 
large portion of the concentrated and explored material has been uploaded on the Conference's website and the Conference Proceedings, with free access, available for any future research (Kalathaki \& Cavas, 2015).

The research is a case study with content analysis of archival material, to answer the basic research question of those specific elements that are not so usual in the common Academic Conferences and can be explored in educational and training peer learning activities, penetrating transversely the three level of Education. During the critical reading of the papers, notes were kept referring to the content divided in the research categories, with comments and interpretations, in a kind of dialogue with the document. The analysis became inductively, that is the categories were not fixed from the beginning, but located by the progress of the analysis of data emerging from the studying archival material (Bird, 1990; Bell, 1997). Finally, there were created 7 thematic categories, corresponding to the research sub-questions-objects: I. The Conceptual Framework, II. The Methodological Framework, III. Organizational Structuring, IV. The Delivered Material, V. Treats and Offers, VI. Reflections, VII. Dissemination of the Results. The Conference aimed to open the island of Crete to the Mediterranean Educational society, to the world, bearing in mind the words of Socrates "I am not an Athenian or a Greek citizen, but a citizen of the world". To expand the boundaries of the mind, the horizons of thought and the criticisms in most untrodden paths of investigation and discovery, promoting the values of Education for Sustainable Development. The questions set in this paper are about those characteristics that make the Conference initiative and pioneering in cultural, outdoor science education, connecting science, education and quality of life in local communities. The point of view of the research was the prism of a training program that can be applied elsewhere, with different target groups, and promotes the aims of participatory acquisition of knowledge by sharing in company, knowledge and wisdom, in moments of wisdom, joy and happiness.

\section{Results and Discussion}

The European Educational Conference "Mediterranean Sea Connects Us: Progress in Education with Local Communities" addressed to executives of Education, of all educational levels, who are interested in collaborating and sharing knowledge and experience in Science, Technology, Education, Training and Entrepreneurship, in an effort to overcome the crisis of values, structures and meanings, additionally to the economic, for better quality of life and progress of the local communities. The Conference organized by the Region of Crete-Chania prefecture, the Regional Administration of Primary \& Secondary Education of Crete (by the Department of Scientific and Pedagogical Guidance of Primary and Secondary Education, the Secondary Education Directorates of Rethymnon and Chania and the School Advisors for Teachers of Natural Sciences and of Engineering in Western Crete, and 6th Region of Primary Education of Heraklion), the Centre for Plasma Physics and Lasers (CPPL), the School of Applied Sciences of the Technological Education Institute of Crete, the Holly Theological School of Halki, and ensured hospitality for all participants. The Conference was in continuation of the Educational Congress on the inquiry based learning in Natural Sciences 'Mediterranean-water line: with the mito of Ariadni, mapping the unknown-setting interdisciplinary the queries in teaching', which took place in Greek language, some days before, in the same region (Kalathaki \& Vlachokyriakou, 2015).

\subsection{The Conceptual Framework}

Teachers need to be properly prepared to innovate in their teachings by introducing the history and philosophy of Natural Sciences. The reconciliation of history and philosophy with science teaching represents the rebirth of the crowded and together innovative approach to their teaching, which embraces the portrayal of the truth, goodness and beauty of Aristotle as modern ideals, supporting the development of knowledge, ethics, aesthetics, behavior and abilities of individuals (Matthews, 1994). Both Congresses attempted to map the unknown in Mediterranean societies, that have played a crucial role in the life and progress of Europe and the west world, in the paths of exploration and discovery of the new and old civil-educational material, to explore the multilevel relationship of Mediterranean societies which are rapidly changing due to geopolitical, digital, economic, social, political and cultural conditions, in the past and in our days. Greece is a European country in the southern Europe, a Mediterranean, and a Balkan one, having close traditional bonds with the Black Sea, having at the same time strong ties with the Middle East and the Arab world, which is an added value for the European perspective. Both Conferences took place in the heavy atmosphere of the painful reality of Syrian refuges in the East Mediterranean, which described very well into a teacher's well-coming text, sent to the Conference's Coordinators, notifying that "Mediterranean was place of philosophy in the ancient years and today became place of tragedy for thousands of refugees".

The purpose of the Conference was to build up joint educational projects that could introduce a more participatory, interdisciplinary, innovative and creative way of teaching and learning of formal and non-formal Education, in the 
framework of the Education for the Sustainable Development, in Science and Technology school teaching, in the neighborhood of the East Mediterranean, to support teachers to pass through the economic crisis with the less disadvantages and damages that can be. The poem 'Ithaki' written by Cavafis, sent the general message and focused on the main hypothesis of the Conference. "As you set out for Ithaca, hope that your journey is a long one, full of adventure, full of discovery. Hope that your journey is a long one ... Keep Ithaca always in your mind. Arriving there is what you're destined for. But do not hurry the journey at all. Better if it lasts for years, so that you're old by the time you reach the island, wealthy with all you have gained on the way, not expecting Ithaca to make you rich. Ithaca gave you the marvelous journey. Without her you would not have set out. She has nothing left to give you now. And if you find her poor, Ithaca won't have fooled you. Wise as you will have become, so full of experience, you will have understood by then what these Ithacas mean". For deepening the conceptual and philosophical framework of the Conference, some days before, the Coordinator delivered the Olympic Games Athens 2004 videos in Opening Ceremony "Citizens of the World welcome to Athens!!!!!” (Athens, 2004).

Educators-officials of high level and much experienced in the three levels of Education from Greece, Cyprus, Turkey and Romania, with representatives from local bodies, the cities and villages of west Crete, were Invited to the Conference to deposit experience, aspects, ideas and expectations on future educational collaboration in the area of Balkans, East Mediterranean and widely. For 100 hours, the participants of the Conference constituted a learning community, and deliberated, in an experiential way, on theoretical and practical issues of scientific and pedagogical guidance, in the following thematic areas: a. multi-cultural past, present, future, b. science, technology, education and quality of life, c. designing educational projects with European dimensions, d. institutional innovations, e. lifelong learning \& local communities, f. achieve funding of a project. Conference's members communicated and shared collaborative activities, adopted attitudes and practices by focusing on significant elements, useful for themselves and for their students and teachers that they educate and train. According to modern aspects of the social interaction theories, in the social constructivism, learning communities provide support to learners to bridge the gap between what they can do by themselves and what they can do when collaborating with others, in a well-organized framework of a supportive learning environment. Studying the sociology of scientific knowledge has explored the importance of social negotiation in the production of facts. Central is the stance that empirical evidence alone underdetermines scientific knowledge, that social construction of knowledge is necessary to move empirical data to established fact (Cunningham et al, 2001).

\subsection{The Methodological Framework}

MacBeath (2005) set the query if teachers can learn and gave by himself the reply. Teachers can learn, but there are also systemic factors that prevent teachers to learn, such are: a. the specialty/expertness of the teaching-cognitive object which they learn and teach to their students-who they do not know it, b. they do not have time to learn, since they are very busy with the teaching and evaluation of their students, c. they have forgotten how to learn, because they have not time and believe that they are experts, so they have no incentive to encourage them to continue learning. On the other hand, there are pressing arguments for the lifelong learning of teachers, such as the children are no longer the same as 20 or 30 years ago, society is more technological, communicative, consumer, and in general we have not yet sufficiently discovered what learning is.

Nevertheless, what is generally accepted, is learning through interactions can build social capital of standards and values for mutual benefit. The context of trust, common values, sense of identity and access knowledge of the others by networking, facilitates learning and leads to personal development and achievement the purpose and objectives of the team task in educational communities, and in all work groups. Knowledge is experiential, is connected with practice, and constructed through interactive processes as collaborative assembly, group exploration, debates etc. Mahatma Gandhi had said that 'an ounce of action is more worth than a ton of teaching, the books offer the knowledge, but the action translates it into understanding'.

In the same direction, the European Commission explores responses for the teacher education and training, with particular concern to develop policies on participative and experiential teaching and learning, mostly giving emphasis in lifelong learning methodologies and initiatives. Peer learning activities are in European Commission's shared policy concern for the systems of continuing professional development, the school leadership, preparing teachers for culturally diverse classrooms, and partnerships between schools and companies, facing the school as a learning community for its teachers. Member States find that this kind of work provides useful learning opportunities for teachers, students and the local societies (SEC, 2007). The organizers of the Conference invited 60 persons, who were professors, teachers, officials and researchers of Primary, Secondary and Higher Education who negotiated the issue of designing and structuring educational and training projects for teaching Natural Science in schools, with 
local communities, in a more participatory, interdisciplinary, innovative and creative way, in the framework of the Education for the Sustainable Development. Peer learning activities carried out on the base of the Science curricula and the European Union's Strategies, the national guidelines in Education for developing ideas and aspects of participants.

The Conference carried out in English language and was open regarding the content, methodology and participants, who were simultaneously trainers and trainees. They experienced the co-construction of the knowledge in many sessions through presentations, discussions, workshops, round tables, visits and cultural happenings for various disciplines. The discussed subjects were about the key competences for active, exploratory, self-regulated, communicative and collaborative learning, changes in teaching with the preparation of more effective learning environments for the science cognitive objects. The participants focused on the development of strategies to integrate the European dimension in cross curriculum teaching and learning, on innovations and creativity in teaching and teacher training through collaborative networks, lifelong learning, etc. In Austria, the Leadership Academy as a forum for system-wide change through nationwide continuing education, offers innovative training for head teachers as well as for other educational leaders. The courses include plenum meetings with motivational lectures, workshops in collaborative coaching groups, reflection on innovation and development of project ideas, learning partnership sessions for the exchange of ideas and collegial brainstorming, workshops for regional networking, etc. (EACEA/Eurydice, 2013).

The Conference was a mix product of educational pathway, lectern, congress, and seminar. It was significantly different from the well-known Conferences in the academic circles and could be an 'unconference'. According to Craig (2006) in Wikipedia, an unconference, also called an open space conference, is a participant-driven meeting. The term unconference has been applied to a wide range of gatherings that try to avoid one or more aspects of a conventional conference, such as fees, sponsored presentations, and top-down organization. Bressen (2006) discusses the possibilities for transformational conferences where the group started organizing wisdom councils, world cafés, and other participatory events within the conference, and volunteering to serve as panel moderators, and trainers of panels, in an effort to shift the culture. Further, they found and developed tools for participatory events that were able to apply more fully at other happenings, such as the 'Meta-Media Cooperation'. Since the goals of the Conference were, among others, experts in Education, to educate those who know less, to skill-share, the participants shared information with each other, in networking, and developed new social connections for future joint projects, etc.

The Conference's Organizational Committee was not able to ensure the budget for all the costs, so the local organizers and teachers offered voluntary the hospitality, accommodation, transportations and food, and participants paid only their tickets to come to Crete. Preparations started 6 months before. Each one of the invited discussants had to choose and present the issue that she/he believed that could contribute to the definition and clarification of the general subject of the Conference Science, Education and progress in Local Communities. The local teachers tried to go against the flow of misery which was immersing day by day because of the economic crisis and tried to be as close as possible to the coming neighbors-colleagues, and offer as more as they could. In Education, the horizons are broaden and the teachers, students, families, and the countries can help each other to live beloved and peacefully together and jointly as citizens of the same space, in the Mediterranean Sea and widely.

\subsection{Organizational Structuring}

The 24 members of the Organizational Committee, the 28 members of Scientific Committee, and 58 participants co-constructed the conference as educational and civil event with the support of four coordinators, two teachers who offered technical support, a website that hosted all the delivered and produced educational material, etc. The 100 hours that discussants spent together was a travel in time and space from the ancient years to nowadays, from the Mediterranean areas where the discussants came to Crete. In four days, with presentations, discussions, laboratories, virtual and field pathways, peer learning activities, visits and cultural happenings, dance, and song, established the jointed way of working and build up educational open courses and projects, introducing to a more participatory, interdisciplinary, innovative and creative way of teaching and learning of formal and non-formal Education, in the framework of the Education for the Sustainable Development.

There were more to tell than those enclosed to the speeches, many the questions, variety the answers to those set primitive queries in the Antiquities Museum of Stockholm, many new eyes on the things, and from differentiated points of viewing the Science Education in this peer learning open Conference.

Sessions. Eighteen sessions took place with chairwomen and chairmen the members of the Scientific Committee. The topics of the sessions were: Science \& Education Cornerstones of Societies, Transformations in Education, Collaborating \& Decision Making, Institutional Innovations, Designing Educational Projects with European 
dimensions, Funding Projects-Strong Points, Education for the Sustainable Development, Sustainable Development \& Local Communities: Basing the Future in the Past, Community Cultural Lessons: Exporting Family Civilization of Quality of Life, Life Long Learning \& Local Communities, Outdoor, Environmental Education: Sea \& Mountain-Excursion, Discovering the Cultural Environment Around: Night Walk around the old city of Rethymnon, sightseeing historical and cultural places, traditional Lunches and Dinners, Visit of the Old city of Chania, walk at the old harbor, drink of Local Herbal Teas at the Venetian Neorio Moro, Morning walk in the countryside's pathways around the conference venue. The 'Cosmos Symposium with the Ancient Greek Natural Philosophers' as the good bye dinner had the ritual approach of the Ancient Greek Symposium's where the Conference's participants took roles of ancient Greek Natural Philosophers and discussed issues about the origin and structure of Universe, in a Theatric Action and scene of a well prepared learning environment for inquiry and discovery very basic scientific notions.

Opening Ceremony. Many important Bodies offered their culture and expertise in the great actions that organized for the invited participants and have mentioned above as organizers. Some of them, also, attended the Opening Ceremony to welcome the participants and other welcome them, in their premises, during the Conference's sessions that they hosted. Also, the support by local teachers and citizens was impressive and offered a great additional value to Crete and Cretan Education, as it expressed in the reflection of the participants.

In the opening session, each delegation introduced itself, in mother tongue, by using English language in the Power Point and Prezi presentations. So mother tongues heard in the Conference Hall and pictures from the countries, cities and educational organizations flooded the hall, gladdens of the ears and eyes, informing about the far places and people, incoming educational civilizations.

The Opening Ceremony closed with the 'Multi-Cultural Dinner' and discussions in companies. Multicultural Dinner had traditional/typical food from the countries of the coming delegations, also music and dance. The Coordinators' welcoming was thankful for the wish to join, and the great honor and glad to open the borders of Crete, and expand more the relationships and collaborations to East Mediterranean, to the neighborhood of Crete, wishing "Let's try our future generation to live and work together in a more peaceful, creative and of happiness way!! We, all, can contribute to this".

Excursions. Exploring the world around, 'Elafonisi geo-site' is a landscape of exquisite natural beauty, an important wetland and station for migratory birds with numerous sand dunes due to Aeolian processes. On the way back from Elafonissi, by the cars of local teachers, they visited the olive press factory on the road to the village of Harhaliana, 4 $\mathrm{km}$ from Kasteli. Then, they went to Lussakies village in the renovated school, where locals have founded a Museum of Music and Dance. The President of the Cultural Association explained the initiative for the establishment of Museum and the creation of a Network of cultural associations of Crete.

Closing of the Conference. It became with a good bye lunch with reflection and evaluation of what happened in the last days, and with discussions for future collaborations. "The conference did not stop on $13^{\text {th }}$ of December 2015, it is continues through distance communications, meditations and reflection that followed via emails, collaborations and partnerships that are building up, highly promising for the future, as the President of the Conference said in the closing session. No one wanted to finish all that felt and experienced in those 100 hours in Crete. In the final lunch, emphasis was given to the value of using the reflection in the didactic practice and in the educational research, and, regarding the training methodology, its importance and significance.

Closing the Conference, one of the Coordinators sent an email to all the participants 'I am back to my house, you also to your homes, and I have the need to say to all the participants of the Conference a huge Thank you for your contribution to this effort to open the educational community of the west Crete to the Mediterranean neighborhood and build up jointly new activities in new directions and educational pathways for becoming Science more attractive to teachers and students with more disciplinary approaches in rich and pluralistic learning environments that we can provide by co-constructing with our friends, colleagues, local bodies, students, educators and learners, trainers and trainees, all together and all the time on the stage. I am sending to you a huge Thank you for the happiness of sharing creative and innovative thoughts, practices, aspects and ideas on the great hypothesis of Education that is the only social sector which is able to undertake the effort to pull the societies out of the crisis. In the Conference's sessions, as in the classrooms and amphitheaters, in any educational action, we are not alone. The educators and the learners who participate in any educational event are simultaneously trainers and trainees carrying with them millions of researchers, philosophers, educators of many centuries ago who support their effort to transform the knowledge and extract the wisdom'.

The perception of a Networked Learning Community of the Postmodern, Realistic Intellectuals is not easy to 
implement within the prevailing educational policy frameworks. It can be formulated in different ways, depending on the educational framework that it is emerged. To belong to such a learning community implies mutual trust and a challenge for educational organizations and systems. As a learning space, it simulates the ancient Greek 'Polis' where people discuss and act, pose crucial issues and respond in a democratic way to the needs of their members and their interlocutors (Elliot, 2005).

\subsection{The Delivered Material}

The Educational Conference was announced through the emails' of the network "Searching for the Ideal Teacher". All the material before and after the Conference, delivered by emails, giving information and incentives to the participants before coming to Crete, also the reflections of the participants after leaving Crete. In order participants to be introduced better in the climate, some days before delivered the Olympic Games Athens 2004 videos about the Opening Ceremony: The 'Zeibekiko' of the opening 'Allegory', the 'Boat Greek Flag', the 'DNA Olive Tree' and 'Clepsydrae', introducing in the ancient Greek spirit and the spirit of fraternization of peoples, such as the participants of Olympic Games welcomed in Athens in 2004. In the same period, a set of selected photos delivered showing national boundaries of some European countries which are only a line and a sign on the scenery, without check points and stops. National borders can change very drastically, awfully and quickly, and when somebody sees the actual borders, can usually tell a lot about bilateral relations and connections of the European countries of the past and current time (Trombino, 2015).

As referred above, the Cavafis poem 'Ithaki' sent the general message and focused on the main hypothesis of the Conference. Also, the poem 'Axion Esti-the Sun the Iliatoras' written by Odysseas Elytis delivered before the arrival of delegations notifying the important points of the meeting: "Hey you, main lands and seas, vineyards and golden olive trees, listen to my notices, in my noontimes. Even if I wander around all lands, only this do I love. From the middle of a cliff to the middle of another sea... I open my mouth and the sea rejoices and takes my words into its dark caves, and whispers them to its young seals, at nights that cry for the suffering of man...".

Seikilos Epitaph contributed to significations of what was going to happen. It is a song considered the oldest Greek one, written in Greek after $200 \mathrm{BC}$, on a tombstone cylindrical column, which music has been survived. Co-exist lyrics of the song along with the symbols of the melody, which is so-called Phrygian type: "As live shine, not at all sorry. For little lasting life, time requires payment".

Among the rest delivered material was the structure of the European Education Systems from Schematic Diagrams of Eurydice document (EC, 2015). All the participants had personal or their institutions' websites that delivered before coming to Crete, so they got previously an idea about the profile of those are going to participate.

\subsection{Treats and Offers}

In the Conference's announcement was written 'We need any type of support from everyone who is available to overcome the crisis (economical, meanings, values, structures). Our neighbors, our friends of Balkan, Mediterranean countries can help us. We supported and we were supported in the past, we can repeat it in the present and in the future, by offering what we have gained in our families, in education, in our communities. Education is the sector of society which is responsible to lead ahead the society, to make society to progress'. Nelson Mandela had said that what counts in life is not mere fact that we have lived. It is what difference we have made into the lives of the others that will determine the significance of the life we lead. Education is the most powerful weapon which we can use to change the world (written on the Google main page the day that he died 18/7/14).

As the life of the school institution is closely linked to that of society, the evolution of society also includes the school institution. As humanity moves towards a thrilling and critical 21 st century, there is a series of reflections on teacher education, whether it is should be the active part of the social transformation, so to what kind of roles should be trained. Former pedagogical training, which was mainly aimed at possessing content, is inappropriate to shape individuals who will respond to modern and future multiple demands, which, even, we do not know well. It is necessary to reposition the problem rather than fix the problem by adding some new courses to the modern curricula. It is about building a new education tailored to today's needs and being able to change based on the new needs that will emerge (Prologue by Mialaret G in Karras \& Wolhuter, 2012).

Gifts offered by the organizers, schools, Universities, research centers, the members of the Scientific Committee, the participants and students. The most impressive gifts were the soaps with very special and beautiful packaging, made by primary students with their teacher, also the Christmas ornaments made of dough by Gymnasium students and ointments of beeswax, honey and medicinal herbs made by teachers in school science labs. All the rooms in the Provincial Press Center decorated with Christmas ornaments, local drink raki, almonds and raisins for resting during 
the short stay. A welcome card in local dialect had put on the room's desk.

Very special lunch and gifts offered the nuns of the St Kyriaki Chrysopigi Monastery. Especially for the Conference dinner, which was an ancient Greek philosophical symposium, locals brought dry fruits, fish, olives, wine, raki, rusks, vegetables, sweets and frumenty (trachanas). Vice-Governor of Crete, who was the Head of Symposium offered the grilled lamp, as they used to do in ancient Greece and traditional sweets of Crete, prepared in his family small industry. Local buses association, the Chania Municipality and teachers offered the transportations to the variety of visiting places and halls where the Conference hosted. The Region of Crete paid for the accommodation and local cultural associations and teachers offered the food and the treats of coffee breaks. Local teachers and parents' associations prepared food for the meals and dinners, also the coffees, drinks and other treats. All the participants brought with them gifts to the Coordinators, and the rest locals.

\subsection{Reflections}

The Conference designed as a training program promoting the aims of participatory acquisition of knowledge by sharing in company, information, knowledge, wisdom and moments of joy and happiness. The initial aim was to link Science, Education and Local Communities, expanding the boundaries of the mind, the horizons of thought and the criticisms in most untrodden paths of investigation and discovery, promoting the values of home civilization. It constituted a hug, a family of memories, a journey into dream, a journey back to time which clarified the past, defined the present and determined the future.

A warm and thankful reflection followed the end of the Conference. 'Thanks to all of you for the great experience that we shared all these days. I feel that I am very lucky because I took part to this unique meeting and I hope to meet you again through another project. We'll be in touch'. 'Thanks to all of you for the contribution to the most unique and productive conference I have ever participated. You all helped to build good relationships among us which is a very important element of collaboration'. 'We will have a future cooperation with you. All in all after everything, and at some distance you should know that all your efforts were truly appreciated'. 'Thank you warmly for the great experience. How do I want this all to get into the classroom!! As much as you said in the closure, everything is done to get to the class and the student. It's a long way...'. 'I would like to thank you for your great job and hospitality during our visit in Crete. Best wishes'. 'It was a great pleasure for to meet you all in this conference. Many thanks to Maria for her inexhaustible imagination and wealth of ideas. The coming period will be a hard working time for settling down valuable thoughts and ideas and trying to transform them in reality. My warmest regards. 'Thank you very much for your great job you did for us last 5 days. The conference was very unique when I compared with other international conferences that I attended in the past. In general and in other conferences, I was attending the sessions that I am interested in and then I was skipping other sessions and people of course. However, in your conference, we were all together from beginning to end of the conference sessions. We eat together, we discussed together, and we listen each other with a great interest. Thanks for the great colleagues for a great job! I think that we are now a great family living in Mediterranean region. Looking forward to seeing you all'. 'It was a great experience for me! Thank you very much for the warm hospitality and the unforgettable moments that we lived all together. Each conference was very fruitful and unique. I hope to meet you again and to create new cooperation in the future! Best wishes'.

The reflection closed with the same way it opened. The Coordinator wrote in an email to the participants, immediately after the end of the Conference and return back home 'Hello! Many times in the day I am thinking the special moments that we have lived together during the 100 hours of the Educational Conference Mediterranean Sea Connects Us: progress in education with local communities. I feel happiness and fullness because I lived it in my life. I thank all of you because of the co-construction of this educational creation. I hope to be able in the future to co-construct a new educational intervention jointly and to share also this with other collaborators from Mediterranean neighborhood and the rest Europe also. Let's try every one keeping in touch in any way. Let's do our best not to lose this Mediterranean core that we built up'. Many answers followed from the participants, such as 'I came back home, to my colleagues, with many new ideas and a lot of information about educational issues'.

To discover together the common Mediterranean civilization, classic, modern, it's symbols and values that once taught and still teaching, influenced and still influence humanity, touched the limits of ecstasy's, since all the spending hours together, the participants co-constructed the educational reality which they lived in a rich, varied and cultural environment based on the educational culture that they brought from their Mediterranean neighborhoods. We have to try much for this because, those we have now are not inherited from the previous generations but we have to inherit to the following. Ancestors of the Mediterranean region had developed communication, connections, and many cultural and economic collaborations in ancient years. N Kazantzakis writes in the book 'The Saviors of God' "You shall never be able to establish in words what you live in ecstasy. But struggle unceasingly to establish it in 
words. Battle with myths, with comparisons, with allegories, with rare and common words, with exclamations and rhymes, to embody it in flesh, to transfix it".

\subsection{Dissemination of the Results}

All participants left Crete with the best impressions and fulfilled of new ideas and expectations, ready to improve their teaching approaches from a more philosophical point of view, thinking more the inquiries of Ancient Greek Naturalistic Philosophers whom scientific aspects shared in the Symposium 'Cosmos' (Papastefanaki \& Kalathaki, 2015). Articles were published in two local newspapers, 'Rethymnian News', 'Cretan Inspection' and Neoi Orizontes' of Rethymnon and Chania prefectures, as press release before the Opening Ceremony and as reflection days later. The titles of the articles were "Mediterranean Sea connects us, meeting of teachers and researchers in the European Conference", "European Educational Congress Mediterranean Sea connects us: advancing Education with local communities"

The website of the Conference International Educational Conference "Mediterranean Sea connects us: progress in education with local communities" will retain uploaded and available the concentrated knowledge and experience in the peer learning activity. The Conference's Proceedings give the opportunity to those are interesting to deepen more in creating this type of educational and training events (Kalathaki \& Cavas, 2015). Widely, the results of the Conference are disseminating through discussions in the fields of educational administration, politics, and research in Sciences, among scientists, teachers, professors, local authorities and bodies, sharing the experience of participation, of belonging in a team. In all discussions, the umbrella-thought was that this type of peer learning activity/open conference can be a horizontal priority for the Mediterranean educational communities, and a factor of innovation and creativity, an area of common research in Education, Science and Culture, a vehicle to overcome the crisis and lead to progress.

The European Educational Conference functioned as a training program which can be applied elsewhere, with different target groups, promoting the aims of participatory acquisition of knowledge by sharing, in companies, wisdom and hours of joy and happiness. All participants together deposited experience, aspects, ideas and expectations on future educational collaboration in the area of Balkans, East Mediterranean and widely, as the Coordinator said in the reflection session. The students of the participant teachers and professors, as future scientists and active citizens in their local communities, and widely, in the future, can approach the scientific everyday issues more interdisciplinary and to find the best solutions into the societal challenges, ensuring a better quality of life. As the nature of scientific inquiry is the importance of subject knowledge and didactic knowledge, in the difficult years of economic crisis, with the consequent crisis of values, meanings and structures, the educators have to investigate more and insist more in the educational civilization for a better and hopeful future of young people.

The Provincial Press Institute, which hosted the Conference, with impressive vision, work and logistics, played a key role in the success of the organization, ensuring, also, the continuity of such events in the Balkans and the Eastern Mediterranean which can be hosted in the future.

\section{Conclusion}

The Common European Principles for Teacher Competences and Qualifications are expressed on the basis of the experience of teachers and teacher educators across Europe and validated by stakeholders. The above described Conference offered the point of view and reflection criteria in designing and assessing education and training actions for the teaching profession. The Conference pointed out some main characteristics of the teaching profession, such are the well-qualified profession, since all teachers are graduates from higher education institutions, the teachers' extensive subject knowledge, since they have good knowledge of their teaching cognitive and pedagogy, the skills and competences required to guide and support learners, and an understanding of the social and cultural dimension of education. It is a profession of lifelong learners and a mobile profession, based on partnership (TCQ, 2010). To initiate more inquiry, participative, societal processes there is need to bring together scientists, researchers, educators from different backgrounds, from different countries, to profit from the different perspectives and views and to exchange ideas on implementation educational creative initiatives. This type of peer learning activities encourage actors in Education to try new practices, to reflect on possible exploitation of strategies, to disseminate good practices in teaching design, in school leadership and pedagogy.

Future Conferences of this type could aim to bring together people from Balkan, from Mediterranean, from European and other countries coming from all over the world, in order to exchange older good practices and ideas, to join and combine their forces for a sustainable future in Education. The collaborations in the past can give birth to 
partnerships in the future. When deepening the relationships, there are expected common benefits for researchers, students, teachers, families, school and university communities, the regions and the countries, in Balkans, the Mediterranean, and the world all. The sense that the Educational Conference accumulated in the participants was the amount of energy that could take off Daedalus and Icarus, again, from Crete, with modern and strong wings in global educational routes.... The Conference opened with Cavafis poem 'Ithaki' and sent the meaningful message "Keep Ithaca always in your mind... do not hurry the journey at all. Better if it lasts for years, so that you're old by the time you reach the island, wealthy with all you have gained on the way, not expecting Ithaca to make you rich...". 'We cannot direct the wind but we can adjust the sails!!!! And since the journey is the goal, we are aiming to it' (Breiting et al, 2005).

\section{Acknowledgements}

Acknowledgements to Anna Papastefanaki, School Teacher of Meleses Lyceum, Crete, to Maria Drakaki, School Advisor for Primary Teachers of Heraklion, Crete and to Panagiotis Simandirakis, Vice Governor for Education and Employment of Crete, Greece for their substantial support in carrying out the Conference

\section{References}

ASE. (2018). Association for Science Education website. Retrieved 26-3-2018 from https://www.ase.org.uk/about-ase/

Athens. (2004). Welcome | ATHENS 2004 Citizens of the World welcome to Athens!!!!! Retrieved 26-3-2018 from https://www.youtube.com/watch?v=hA7U8vCq2mQ

Bell J. (1997). Methodological Planning of Pedagogy and Social Research. Gutenberg Publications: Athens.

Bird M. (1990). The implementation of educational policy: $\alpha$ case study of the implementation of the Open College of South London, Thesis, University of London.

Bressen T. (2006). Possibilities for transformational conferences. Retrieved 24-3-2018 from https://www.treegroup.info/library/Transformational_Conferences.pdf

Cavafis C.P. Ithaca Poem, with Sean Connery \& Vangelis, Retrieved from https://www.youtube.com/watch?v=1n3n2Ox4Yfk

Craig, Kathleen (June 6, 2006). "Why "unconferences" are fun conferences". Business 2.0 Magazine, in Wikipedia.

Cunningham M. C., Meyer Z.M., \& Avery L. (2001). Promoting Sociologically Authentic Inquiry in School Science Communities. Paper presented at the Annual Meeting of the National Association for Research in Science Teaching, St. Louis, MO.

Doumas C. (2008). The island of Aegean civilization, Kathimerini newspaper, insert Arts \& Letters, Sunday, September 14, 2008.

EACEA/Eurydice. (2013). European Commission/EACEA/Eurydice, 2013. Key Data on Teachers and School Leaders in Europe. 2013 Edition. Eurydice Report. Luxembourg: Publications Office of the European Union, ISBN 978-92-9201-412-4. Retrieved from http://eacea.ec.europa.eu/education/eurydice

Earth Charter. (2000). Earth Charter Initiative. Retrieved from http://www.earthcharter.org, retrieved 090316

EC. (2015). The Structure of the European Education Systems 2015/16: Schematic Diagrams. Eurydice Facts and Figures. Luxembourg: Publications Office of the European Union, European Commission/EACEA/Eurydice.

Elliot J. (2005). The Teacher as member of a Networked Learning Community, Chapter in book Training and professional development of teachers by Mpagakis $G$ (editing). Metaixmio Publications, Athens.

GR. (2014). "Year of the Mediterranean" Greek and Italian Presidency of the Council of the European Union, www.gr2014.eu

Hejll L., \& Klippstom H. (editors) (2007). Travel in Time and Space. Museum of National Antiquities of Stockholm, Sweden.

https://issuu.com/kalathakimaria/docs/education_conference_2015_proceedin

Iosifidis Th. (2003). Qualitative Data Analysis in Social Sciences. Kritiki Publications, Athens. 
Kalathaki M. (2015). Mediterranean sea connects us: advancing education with local communities-collaborators in the past, partners in the future, Proceedings of International Educational Conference "Mediterranean Sea Connects Us: Progress in Education with Local Communities", West Crete 9-13 December 2015, Region of Crete, ISBN 978-960-99262-2-5, Available on E-Book:

Kalathaki M., \& Cavas B. (Editing) (2015). Proceedings of the European Educational Conference "Mediterranean Sea Connects Us: Progress in Education with Local Communities", 9-13 December 2015, West Crete, Greece, Office of School Advisors for secondary Teachers in Chania, available 23-03-2018 on the website https://issuu.com/kalathakimaria/docs/education_conference_2015_proceedin http://mediterraneanconnectsusedu2015.weebly.com

Kalathaki M., \& Vlachokyriakou F (Editing) (2015) Proceedings of the Educational Congress on the inquiry based learning in Natural Sciences 'Mediterranean-water line: with the mito of Ariadni, mapping the unknown-setting interdisciplinary the queries in teaching', West Crete 4-8 December 2015, Greece, Office of School Advisors for secondary Teachers in Chania, available 23-03-2018 on the website http://mediterraneanmappingunknownedu.weebly.com/

Karras K., \& Wolhuter C. (2012). Teachers' Education in the 21st century. Contemporary trends and challenges in the teacher educational systems in 90 countries, Mialaret Gaston Prologue, Ion Publications, Athens

MacBeath J. (2005). Can Teachers to Learn? Chapter in book Training and professional development of teachers by Mpagakis G (editing), Metaixmio Publications, Athens

Matthews M. (1994). Science Teaching, the role of history and philosophy of Science, Routledge, Translation in Greek Language by Angeliki Moumtzi, Epikendro Publications

Olympic Games Athens (2004). Videos. Retrieved from https://www.youtube.com/watch?v=Zfla6ZScIsI

Papastefanaki A., \& kalathaki M. (2015). COSMOS: with the ancient Greek natural philosophers-an approach ofthe Ancient Greek Symposium's ritual. Retrieved 26-3-2018 from http://cosmosancientgreeksymposium.weebly.com/the-ritual.html

SEC. (2007). Improving the Quality of Teacher Education, Communication from the Commission to the Council and the European Parliament, \{SEC(2007) 931, SEC(2007)933 Commission of the European Communities, Brussels, 3.8.2007, $\operatorname{COM}(2007) 392$ final

TCQ. (2010). The Common European Principles for Teacher Competences and Qualifications, Identifying Skill Needs. Retrieved 27-01-2010 from http://www.cedefop.europa.eu/themes/theme_a/default.asp

Trombino D. (2015). Incredible Photos of The Places Where One Country Ends and Another Begins, Posted Jun 02, by Dominic Trombino. Retrieved from http://www.omgfacts.com/lists/21331/21-Incredible-Photos-Of-The-Places-Where-One-Country-Ends-And-An other-Begins?utm_source=Facebook\&utm_medium=Viral\&utm_campaign $=$ onsite_share 